mgr inż. Marcin Nowak

dr hab. inz. Stanistaw Rawicki

Politechnika Poznańska

\title{
Wpływ wielkości odzyskiwanej energii na algorytm energooszczędnej jazdy pojazdu tramwajowego
}

\begin{abstract}
$W$ artykule omówione sq wyniki badań analitycznych dotyczacych wptywu wielkości odzyskiwanej energii na algorytm energooszczędnej jazdy pojazdu tramwajowego; wielkość ta może zmieniać się od zera do maksymalnej wartości energii, która może być generowana przez energoelektroniczne układy odzyskiwania energii przy hamowaniu. Przy optymalizacji uwzględnia się systemowe ograniczenia, np. dopuszczalna prędkość maksymalna, wielkość przyspieszenia i opóźnienia, tzw. przyczepność i dopuszczalne obciażenie trakcyjnych silników napędowych.
\end{abstract}

\section{Wprowadzenie}

W Instytucie Elektrotechniki i Elektroniki Przemysłowej Politechniki Poznańskiej, np. [1, 3, 4], a także $w$ innych ośrodkach naukowych, np. [2], realizowane są prace badawcze, mające na celu wyznaczenie takich algorytmów przejazdu pojazdu tramwajowego, które zapewniają minimalne zużycie energii. Przedmiotem badań są tramwaje wyposażone w napędowe silniki szeregowe prądu stałego albo w trójfazowe silniki indukcyjne.

Przy zadanej długości trasy tramwaju oraz dla określonego czasu jazdy, a więc dla identycznej wartości prędkości średniej, otrzymuje się wiele sposobów wykonania przejazdu pojazdu tramwajowego. Najlepsze zaplanowanie przebiegu fazy rozruchu, etapu jazdy ze stałą prędkością, fazy wybiegu i części ruchu, w której występuje hamowanie tramwaju, umożliwia uzyskanie minimalizacji zużycia energii elektrycznej.

Systemy elektryczne umożliwiające rekuperację energii elektrycznej podczas hamowania pojazdu tworzą nowoczesne warunki do oszczędzania energii elektrycznej zużywanej przez tramwaje. W warunkach miejskich ruch pojazdu tramwajowego realizowany jest często przy różnorodnych zakłóceniach, wywołanych np. globalnymi lub lokalnymi ograniczeniami prędkości jazdy, nieprzewidzianymi dodatkowymi postojami. Zakłócenia ruchu tramwajów wywołują dość często potrzebę dodatkowego hamowania pojazdu na trasie. Przeprowadzone obliczenia wykazują że w takich przypadkach stosowanie urządzeń elektronicznych, umożliwiających odzysk energii podczas hamowania tramwaju, jest szczególnie korzystne $\mathrm{z}$ punktu widzenia całkowitego, szczegółowego bilansu zużycia energii elektrycznej. Przy dynamicznie zmieniających się warunkach jazdy, systemy z rekuperacja energii pozwalają na zaoszczędzenie nawet do kilkudziesięciu procent energii, jeśli porównań dokonuje się $\mathrm{z}$ tramwajami bez możliwości odzysku energii.
W niniejszym artykule przedstawione są rezultaty obliczeń związanych z wpływem wielkości odzyskiwanej energii elektrycznej na algorytm energooszczędnej jazdy pojazdu tramwajowego. Wielkość energii w procesie rekuperacji może zmieniać się od wartości równej zeru do maksymalnej wartości energii, która może być generowana do sieci przez odpowiednie układy energoelektroniczne tramwaju. Przy optymalizacji uwzględnia się także systemowe ograniczenia, przykładowo: dopuszczalną prędkość maksymalną, wielkość przyspieszenia i opóźnienia tramwaju, tzw. przyczepność oraz dopuszczalne obciążenie silników napędowych.

\section{Matematyczny opis ruchu tramwaju}

W niniejszej pracy rozpatrywany jest pojazd tramwajowy wyposażony $\mathrm{w}$ napędowe silniki szeregowe prądu stałego, które zasilane są z układu przekształtnikowego w postaci czoperów. Etap rozruchu złożony jest $\mathrm{z}$ następujących trzech części: rozruch przy stałej, dużej wartości prądu, okres osłabiania wzbudzenia silnika (przy pełnym napięciu sieci), wzrost prędkości pojazdu (w trzeciej części rozruchu) przy pełnym napięciu sieci i stałej wartości współczynnika osłabienia wzbudzenia. Ruch pojazdu o masie $m$ opisany jest przez następujące równanie:

$$
k_{W} m D v=F_{P}-W(v)
$$

gdzie:

$k_{W}-$ współczynnik mas wirujących,

$D$ - symbol różniczkowania $\mathrm{d} / \mathrm{dt}$,

$v$ - prędkość pojazdu,

$F_{P}-$ siła pociagowa,

$W(v)$ - opory trakcji aproksymowane przez funkcję kwadratową za pomocą wzoru Coopera. 
Prędkość tramwaju jest powiązana z prędkością kątową $\omega$ silników w następujący sposób:

$$
v=\omega r / z
$$

gdzie:

$r$-promień koła napędowego,

$z$ - przełożenie przekładni mechanicznej.

Związek między siłą napędową i momentem użytecznym silnika $T$ ma następującą postać:

$$
F_{P}=n_{S} T z \eta / r
$$

gdzie:

$n_{S}$ - liczba silników napędowych,

$\eta$-sprawność przekładni mechanicznej.

Prąd wzbudzenia i strumień magnetyczny są powiązane $\mathrm{w}$ ramach charakterystyki magnesowania. Wartość momentu użytecznego na wale silnika otrzymuje się po obliczeniu różnicy momentu elektromagnetycznego, momentu strat mechanicznych oraz momentu strat w żelazie. Energię elektryczną En pobieraną przez pojazd tramwajowy oblicza się poprzez całkowanie iloczynu napięcia zasilającego $U$ silnika, prądu $I$ oraz liczby silników. W wyniku występowania wielu nieliniowości, tylko metody numeryczne umożliwiają obliczenie minimum zużycia energii elektrycznej w ramach matematycznego modelu opisującego ruch tramwaju.

\section{Przyklady obliczeń}

Obliczenia zostały tutaj przeprowadzone dla zmodernizowanej wersji tramwaju typu $105 \mathrm{~N}$, zawierającego czopery zasilające 4 jednakowe silniki szeregowe prądu stałego o łącznej mocy $160 \mathrm{~kW}$. Tylko część uzyskanych wyników zostanie przedstawiona $\mathrm{w}$ tym artykule. Rys. 1-17 dotyczą przejazdu tramwaju o masie równej $22000 \mathrm{~kg}$. Taka masa odpowiada obciążeniu pojazdu przy liczbie pasażerów wynoszącej 80, która stanowi $64 \%$ znamionowego obciążenia tramwaju (znamionowa liczba to 125 pasażerów o średniej masie 70kg). Przez współczynnik rekuperacji $k r$ określono, jaka część możliwej energii oddawana jest do sieci podczas hamowania pojazdu. Jeżeli $k r=0$, to nie ma żadnego odzysku energii; rekuperacja jest największa, gdy $k r=1$.

Na rys. 1-6 przedstawiono wyniki obliczeń dla różnych przejazdów pojazdu tramwajowego na trasie o długości $600 \mathrm{~m}$, czasu jazdy $60 \mathrm{~s}$ i wartości współczynnika rekuperacji $k r=0,5$. Rys. 1 dotyczy najbardziej ogólnego przypadku ruchu tramwaju, obejmującego 4 fazy jazdy: rozruch, jazdę ze stałą prędkością, wybieg i hamowanie, przy czym wartości prędkości granicznych dla kolejnych faz jazdy są oznaczone za pomocą punktów. Wielkość zużycia energii elektrycznej $(0,839 \mathrm{kWh})$ ma tutaj wartość pośrednią pomiędzy najlepszym i najgorszym wariantem przejazdu tramwaju. Energooszczędny ruch pojazdu (minimalne zużycie energii równe $0,824 \mathrm{kWh}$ ) na badanym odcin$\mathrm{ku} 600 \mathrm{~m}$ ma miejsce wtedy, gdy najdłuższa jest faza wybiegu oraz nie występuje etap jazdy ze stałą prędkością (rys.2). Najbardziej energochłonna jazda (maksymalne zużycie energii równe $0,916 \mathrm{kWh}$ ) dotyczy pokazanego na rys. 3 przypadku, gdy w ogóle nie ma wybiegu, natomiast etap jazdy ze stałą prędkością jest najdłuższy.

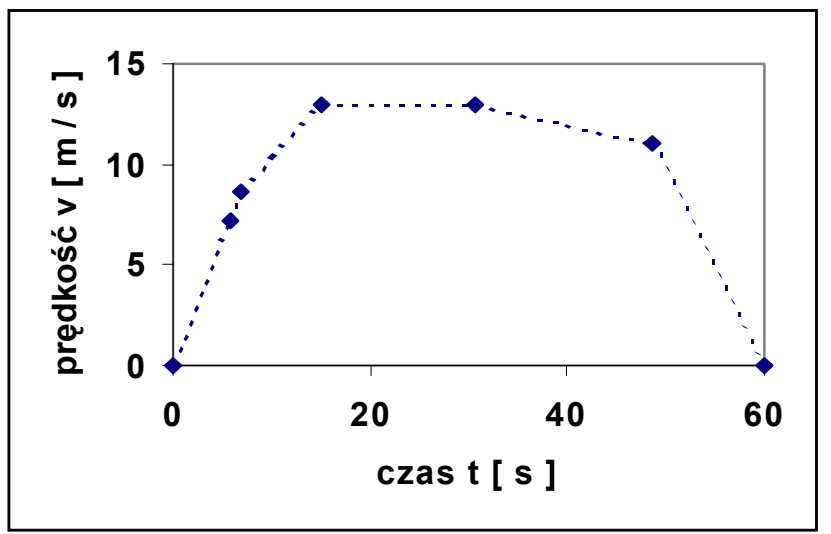

Rys. 1. Przykładowy przejazd dla danych: długość trasy: $600 \mathrm{~m}$, czas: 60 s, współcz. rekuperacji: 0,5 ; zużycie energii: $0,839 \mathrm{kWh}$



Rys. 2. Energooszczędny przejazd przy najdłuższym wybiegu; długość trasy: $600 \mathrm{~m}$, czas: 60 s, współcz. rekuperacji: 0,5; zużycie energii: $0,824 \mathrm{kWh}$

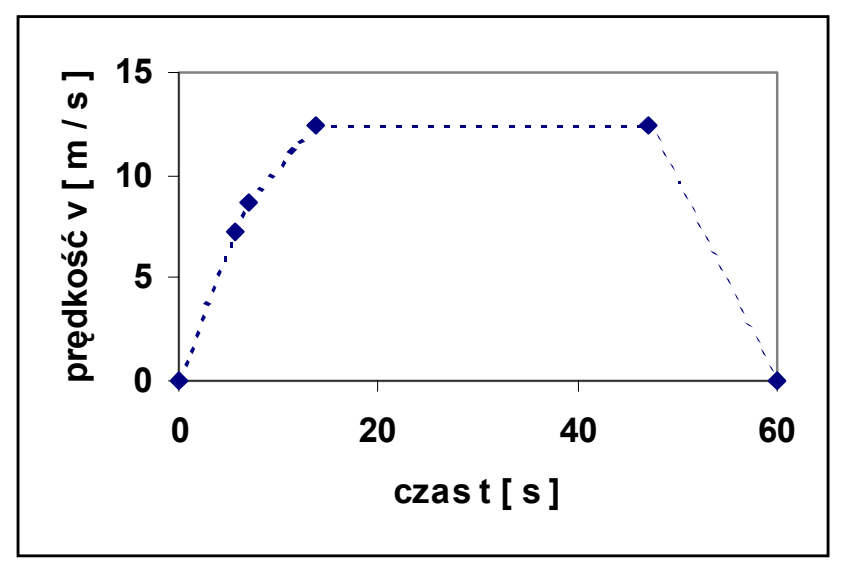

Rys. 3. Energochłonny przejazd bez fazy wybiegu; długość trasy: $600 \mathrm{~m}$, czas: $60 \mathrm{~s}$, najdłuższy etap jazdy ze stałą prędkością; współcz. rekuperacji: 0,5 ; zużycie energii: $0,916 \mathrm{kWh}$ 




Rys. 4. Dane przejazdów: $600 \mathrm{~m}, 60 \mathrm{~s}, k r=0$; całkowita energia w funkcji prędkości końcowej (m/s) rozruchu: a) 12,46; b) 12,66; c) 12,86 ; d) 13,06 ; e) 13,25 ; f) 13,43 ; g) 13,6 ; h) 13,78 ; i) 13,96

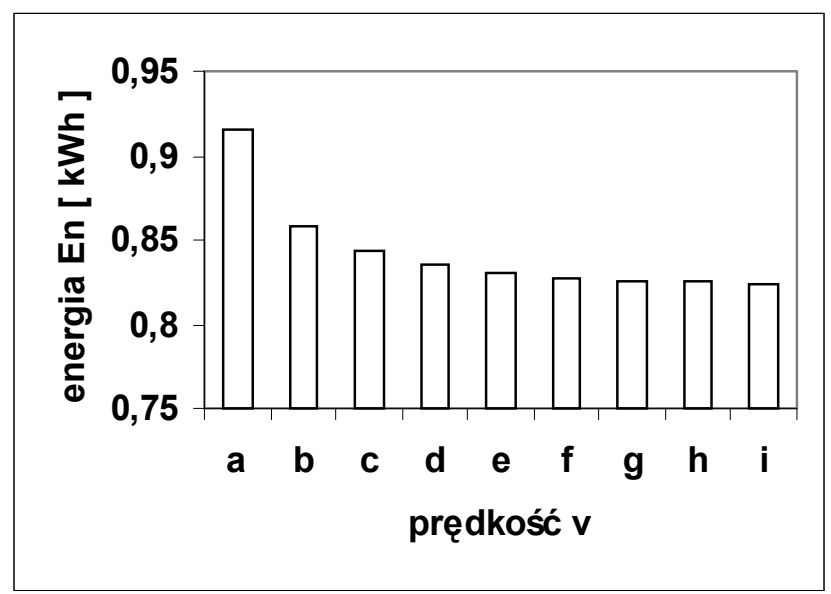

Rys. 5. Dane przejazdów: $600 \mathrm{~m}, 60 \mathrm{~s}, k r=0,5$; całkowita energia w funkcji prędkości końcowej (m/s) rozruchu: a) 12,46; b) 12,66; c) 12,86 ; d) 13,06 ; e) 13,25 ; f) 13,43 ; g) 13,6 ; h) 13,78 ; i) 13,96



Rys. 6. Dane przejazdów: $600 \mathrm{~m}, 60 \mathrm{~s}, k r=1$; całkowita energia w funkcji prędkości końcowej (m/s) rozruchu: a) 12,46; b) 12,66; c) 12,86 ; d) 13,06 ; e) 13,25 ; f) 13,43 ; g) 13,6 ; h) 13,78 ; i) 13,96

Dla trzech różnych wartości współczynnika rekuperacji, rys. 4-6 dotyczą całkowitej energii elektrycznej pobieranej przez trakcyjne silniki napędowe, przy czym energia jest podana $\mathrm{w}$ funkcji prędkości końcowej fazy rozruchu. Interesujący jest fakt, że ze wzrostem współczynnika $k r$ zmniejsza się procentowy wzrost zużycia energii en $\mathrm{w}$ odniesieniu do przypadku energooszczędnego ruchu pojazdu tramwajowego z najdłuższym wybiegiem. Przy braku etapu wybiegu dla jazdy energochłonnej, dla wartości współczynnika rekuperacji: $0 ; 0,5$ oraz 1 , wzrosty zużycia energii en wynoszą odpowiednio: $14,8 \%, 11,2 \%$ i $5,8 \%$. W badanym przypadku, gdy odległość $600 \mathrm{~m}$ między przystankami jest nieduża, wielkość odzyskiwanej energii podczas hamowania pojazdu nie ma wpływu na algorytm energooszczędnej jazdy tramwaju; dla różnych wartości $k r$ czas i droga jazdy podczas rozruchu, wybiegu, a następnie hamowania są odpowiednio takie same.

Na rys. 7-10 podano wyniki obliczeń dla przejazdów tramwaju na dłuższej trasie $(900 \mathrm{~m})$ i dla czasu jazdy 90s (ta sama prędkość średnia jak na rys. 1-6). Rys. 7 przedstawia wybrany $(k r=0,5)$ przejazd z minimalnym zużyciem energii $(0,946 \mathrm{kWh})$; wybieg jest tu najdłuższy i nie ma jazdy ze stałą prędkością. Dla różnych wartości $k r$, rys. 8-10 dotyczą całkowitej energii zużywanej przez silniki napędowe, a energia jest tutaj funkcją prędkości końcowej rozruchu. Dla współczynników rekuperacji: $0 ; 0,5$ oraz 1 , procentowe różnice en pomiędzy największym i minimalnym zużyciem energii wynoszą odpowiednio: 20,9\%, 14\% i 5,9\%. Można zauważyć, że obecnie tylko dla przypadków zilustrowanych na rys. 8 i 9 (współczynnik rekuperacji $k r=0$ i 0,5$)$ wielkość odzyskiwanej energii przy hamowaniu nie ma wpływu na algorytm energooszczędnej jazdy. Na rys. $10(k r=1)$, przejazd energooptymalny zawiera zarówno etap jazdy ze stałą prędkością (długość 162m), jak i wybieg o długości 563m.

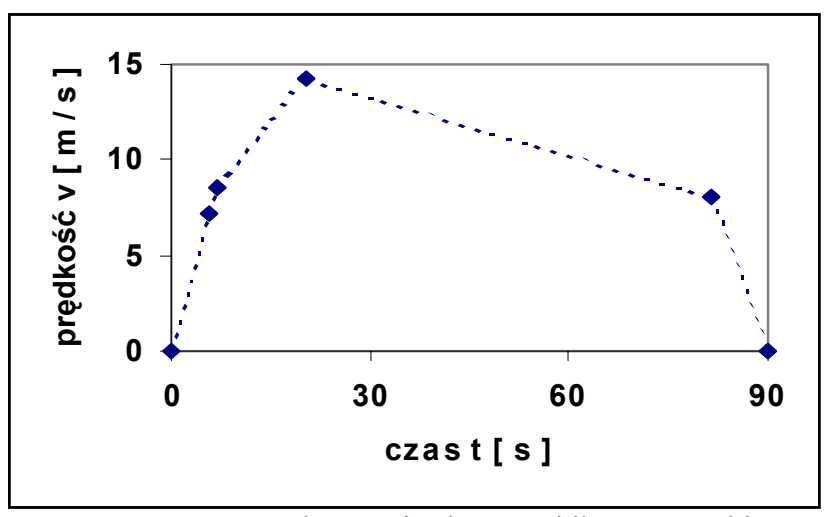

Rys. 7. Energooszczędny przejazd przy najdłuższym wybiegu; brak etapu jazdy ze stałą prędkością; długość trasy: $900 \mathrm{~m}$, czas: 90s, współcz. rekuperacji: 0,5; zużycie energii: $0,946 \mathrm{kWh}$



Rys. 8. Dane przejazdów: 900m, 90s, $\mathrm{kr}=0$; całkowita energia w funkcji prędkości końcowej (m/s) rozruchu: a) 11,33 ; b) 11,65; c) 12,05 ; d) 12,4 ; e) 12,8 ; f) 13,17 ; g) 13,55 ; h) 13,92 ; i) 14,29 


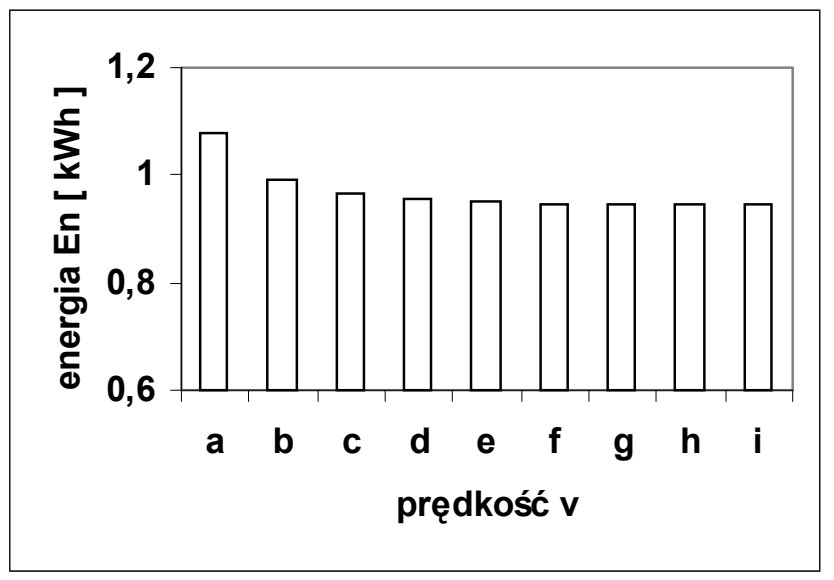

Rys. 9. Dane przejazdów: $900 \mathrm{~m}, 90 \mathrm{~s}, \mathrm{kr}=0,5$; całkowita energia w funkcji prędkości końcowej (m/s) rozruchu: a) 11,33; b) 11,65; c) 12,05 ; d) 12,4 ; e) 12,8 ; f) 13,17 ; g) 13,55 ; h) 13,92 ; i) 14,29



Rys. 10. Dane przejazdów: $900 \mathrm{~m}, 90 \mathrm{~s}, \mathrm{kr}=1$; całkowita energia $\mathrm{w}$ funkcji prędkości końcowej (m/s) rozruchu: a) 11,33; b) 11,65; c)

12,05 ; d) 12,4 ; e) 12,8 ; f) 13,17 ; g) 13,55 ; h) 13,92 ; i) 14,29

Dla czasu jazdy 140s na długim odcinku $1400 \mathrm{~m}$ (długość typowa dla trasy szybkiego tramwaju), zamieszczono wyniki obliczeń na rys. 11-14 (prędkość średnia całego przejazdu wynosiła tutaj $10 \mathrm{~m} / \mathrm{s}$, czyli była taka jak na rys. 1-10). W tym wariancie stwierdza się wyraźną zależność algorytmu energooszczędnej jazdy od wielkości odzyskiwanej energii. Na rys. 11 i $13(k r=0,5)$ przejazd z minimalnym zużyciem energii ma fazę jazdy ze stałą prędkością na długości $643 \mathrm{~m}$ i wybieg o długości $628 \mathrm{~m}$.

Dla najmniejszego poboru całkowitej energii, na rys. 12, 14 (odpowiednio $k r=0$ oraz $k r=1$ ) konieczna jest zarówno faza stałej prędkości $(484 \mathrm{~m}$ na rys. $12 \mathrm{i}$ $816 \mathrm{~m}$ na rys. 14), jak i wybieg (odpowiednio $757 \mathrm{~m} \mathrm{i}$ $477 \mathrm{~m})$.

Na rys. 12-14 całkowita energia elektryczna jest funkcją prędkości końcowej rozruchu. Dla współczynników rekuperacji: $0 ; 0,5$ oraz 1 , procentowe różnice en pomiędzy największym i najmniejszym zużyciem energii wynoszą odpowiednio: 19,1\%, $11,7 \%$ i $4,6 \%$.

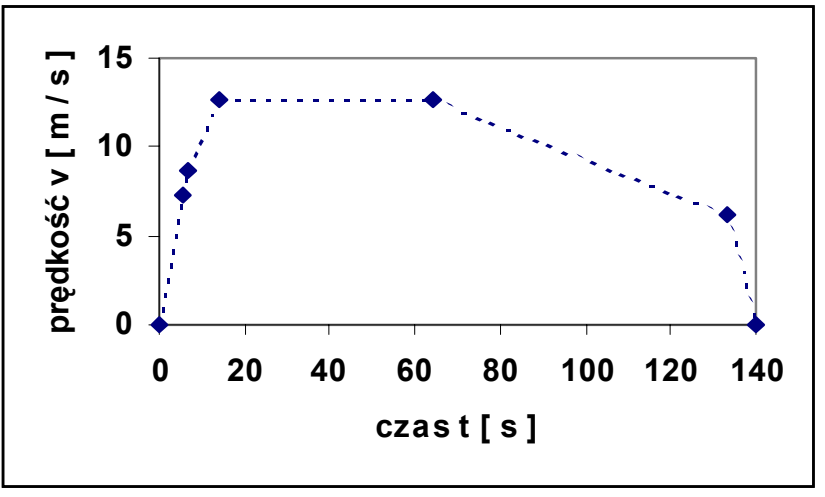

Rys. 11. Przejazd z minimalnym zużyciem energii; obecność fazy wybiegu i jazdy ze stałą prędkością; długość trasy: $1400 \mathrm{~m}$, czas: 140s, współcz. rekuperacji: 0,5; zużycie energii: 1,281 kWh

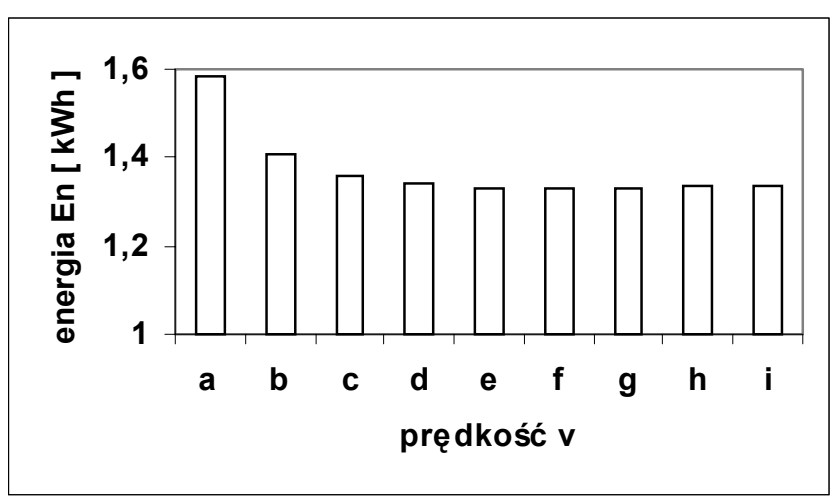

Rys. 12 . Dane przejazdów: $1400 \mathrm{~m}, 140 \mathrm{~s}, \mathrm{kr}=0$; całkowita energia w funkcji prędkości końcowej (m/s) rozruchu: a) 10,77; b) 11,15; c) 11,65 ; d) 12,15 ; e) 12,7 ; f) 13,37 ; g) 14,25 ; h) 15 ; i) 15,71

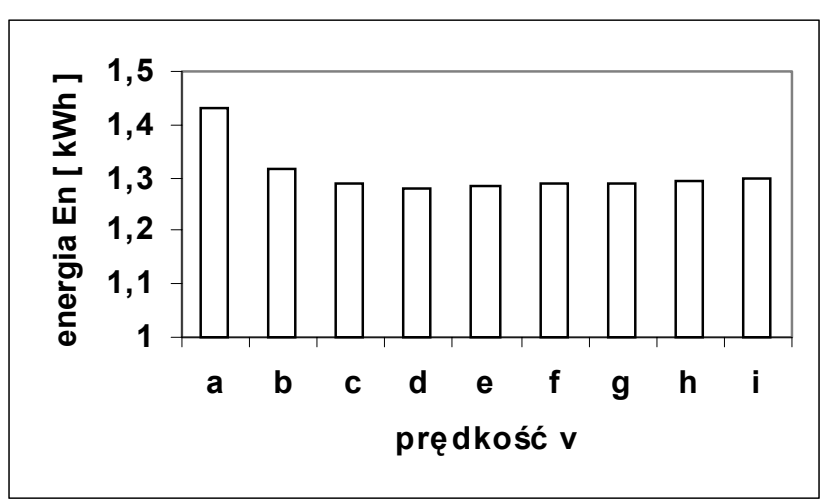

Rys. 13. Dane przejazdów: $1400 \mathrm{~m}, 140 \mathrm{~s}, \mathrm{kr}=0,5$; całkowita energia w funkcji prędkości końcowej $(\mathrm{m} / \mathrm{s})$ rozruchu: a) 10,77 ; b) 11,15 ; c) 11,8 ; d) 12,63 ; e) 13,2 ; f) 13,8 ; g) 14,4 ; h) 15 ; i) 15,71

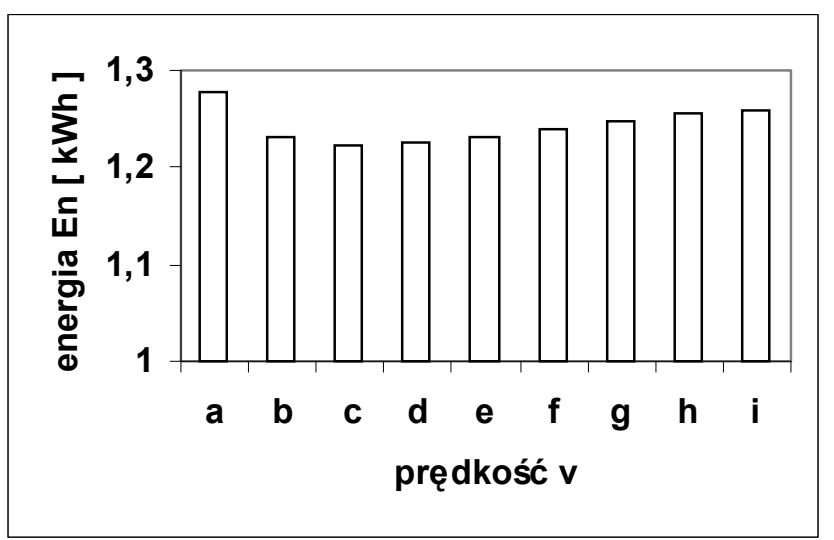

Rys. 14. Dane przejazdów: $1400 \mathrm{~m}, 140 \mathrm{~s}, \mathrm{kr}=1$; całkowita energia w funkcji prędkości końcowej (m/s) rozruchu: a) 10,77; b) 11,15; c) 11,75 ; d) 12,3 ; e) 12,9 ; f) 13,55 ; g) 14,25 ; h) 15 ; i) 15,71 
Rys. 15-17 wiążą się z badaniami wpływu prędkości pojazdu tramwajowego na algorytm energooszczędnego przejazdu tramwaju na trasie pomiędzy kolejnymi przystankami. W tym przypadku wyniki obliczeń są przedstawione dla takiej samej wartości współczynnika rekuperacji $k r=0,5$. Na rys. 15 (długość trasy: $1400 \mathrm{~m}$, czas jazdy: 130s), najmniejsze zużycie energii uzyskuje się, gdy jazda ze stałą prędkością odbywa się na odcinku 492,3m, wybieg: $708,5 \mathrm{~m}$, rozruch i hamowanie: $172,2 \mathrm{~m}$ i $27 \mathrm{~m}$. Zużycie energii dla różnych algorytmów przejazdu: maksimum: 1,543 $\mathrm{kWh}$, minimum: $1,376 \mathrm{kWh}$ (procentowa różnica en: $12,1 \%$ ). Dla szybkiej (w porównaniu z poprzednimi przykładami) jazdy (rys. 16, czas: 115 s, trasa: $1400 \mathrm{~m}$ ), energooszczędny przejazd odbywa się przy najdłuższym wybiegu $(833,2 \mathrm{~m})$ i bez jazdy ze stałą prędkością; rozruch jest na odcinku $519,5 \mathrm{~m}$, a hamowanie: $47,2 \mathrm{~m}$. Dla różnych sposobów przejazdu maksymalne zużycie energii to $1,788 \mathrm{kWh}$, a minimalne: $1,594 \mathrm{kWh}$ (różnica en: 12,2\%).

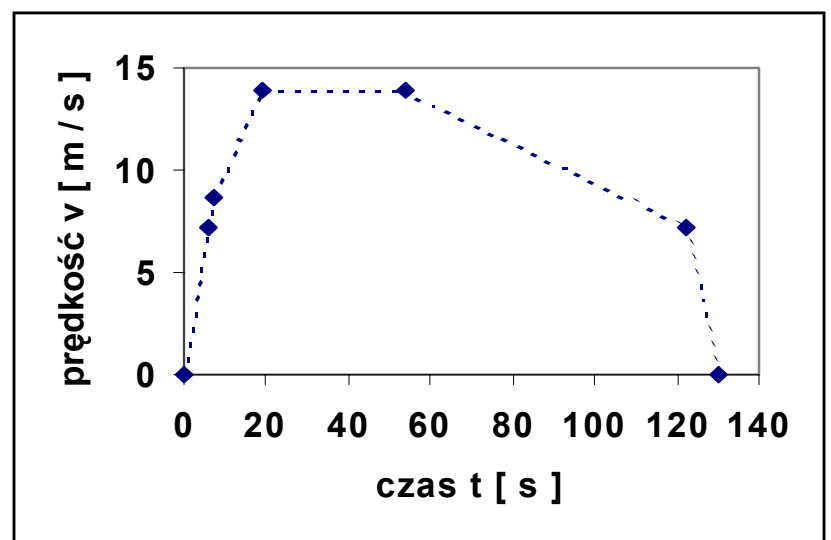

Rys. 15. Przejazd z minimalnym zużyciem energii; obecność fazy wybiegu i jazdy ze stałą prędkością; długość trasy: 1400m, czas: 130s, współcz. rekuperacji: 0,5; zużycie energii: 1,376 kWh

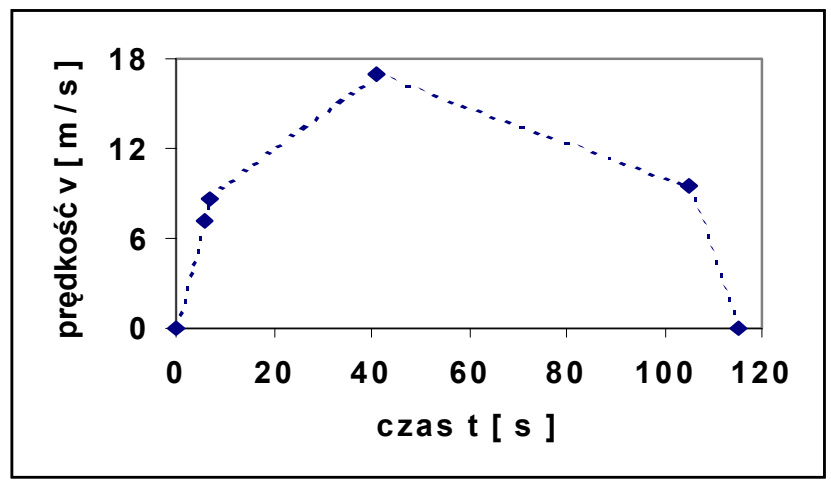

Rys. 16. Energooszczędny przejazd - najdłuższy wybieg i brak etapu jazdy ze stałą prędkością; długość trasy: $1400 \mathrm{~m}$, czas: $115 \mathrm{~s}$, współcz. rekuperacji: 0,5 ; zużycie energii: $1,594 \mathrm{kWh}$

Podczas badań dla trasy $900 \mathrm{~m}$ (część wyników na rys. 7-10), wykonano obliczenia również dla średnich prędkości tramwaju większych i mniejszych niż $10 \mathrm{~m} / \mathrm{s}$. Dla danych: $900 \mathrm{~m}, 80 \mathrm{~s}, k r=0,5 \mathrm{~s}$, jazda $\mathrm{z}$ najmniejszym zużyciem energii nie miała fazy jazdy ze stałą prędkością, a wybieg był najdłuższy $(535,5 \mathrm{~m})$; etap rozruchu miał długość 304,7m, a hamowanie: $59,8 \mathrm{~m}$. Dla zużycia energii przy różnych algorytmach jazdy otrzymano: maksimum: $1,276 \mathrm{kWh}$, minimum: $1,138 \mathrm{kWh}$, a więc procentowa różnica en wynosi $12,1 \%$.

Rys. 17 dotyczy również odległości 900m między przystankami, przy czym jazda odbywa się ze zmniejszoną prędkością (czas przejazdu: 110s w porównaniu z czasem 90s na rys. 7-10). Tym razem najdłuższy wybieg nie zapewnia minimalnego poboru energii; minimum zużycia energii $(0,765 \mathrm{kWh})$ uzyskuje się dla jazdy ze stałą prędkością na odcinku $293,8 \mathrm{~m}$ i wybiegu o długości $531 \mathrm{~m}$ (rozruch jest na odcinku o długości 61,3m; długość hamowania to 13,8m).

Procentowa różnica en między maksymalną i minimalną energią równa się $13,9 \%$.



Rys. 17. Przejazd z minimalnym zużyciem energii; obecność fazy wybiegu i jazdy ze stałą prędkością; długość trasy: 900m, czas: 110 s, współcz. rekuperacji: 0,5 ; zużycie energii: $0,765 \mathrm{kWh}$

\section{Podsumowanie}

Dla określonej trasy tramwaju i czasu jazdy jest wiele sposobów realizacji przejazdu. Optymalne zaplanowanie fazy rozruchu, jazdy ze stałą prędkością oraz wybiegu i hamowania umożliwia minimalne zużycie energii. $W$ artykule przedstawiono rezultaty obliczeń związanych z wpływem wielkości odzysku energii na algorytm energooszczędnej jazdy tramwaju. Wielkość energii $\mathrm{w}$ procesie rekuperacji może zmieniać się od zera do maksymalnej wartości generowanej do sieci przez układy energoelektroniczne pojazdu. Najczęściej przy najdłuższym wybiegu jest minimum zużycia energii. Pokazano jednak i takie warianty przejazdu tramwaju, dla których algorytm energooszczędnej jazdy zależy od wielkości odzyskiwanej energii.

\section{Literatura}

[1] Frackowiak J.: Metoda obliczania jazd energooszczędnych pojazdu tramwajowego napędzanego trójfazowymi silnikami indukcyjnymi. Praca doktorska, Politechnika Poznańska, 1995. 
[2] Kacprzak J.: Automatyka i sterowanie elektrycznych pojazdów trakcyjnych. WKiE, Warszawa, 1981.

[3] Rawicki S.: Modern System of Tram Vehicle Run for City Conditions in Accordance with Criterion of Minimum Energy. AMSE - book, 2007, pp. 129-138.
[4] Zielińska M.: Racjonalizacja zużycia energii w ruchu miejskim elektrycznych szynowych pojazdów trakcyjnych. Praca doktorska, Politechnika Poznańska,1993. 